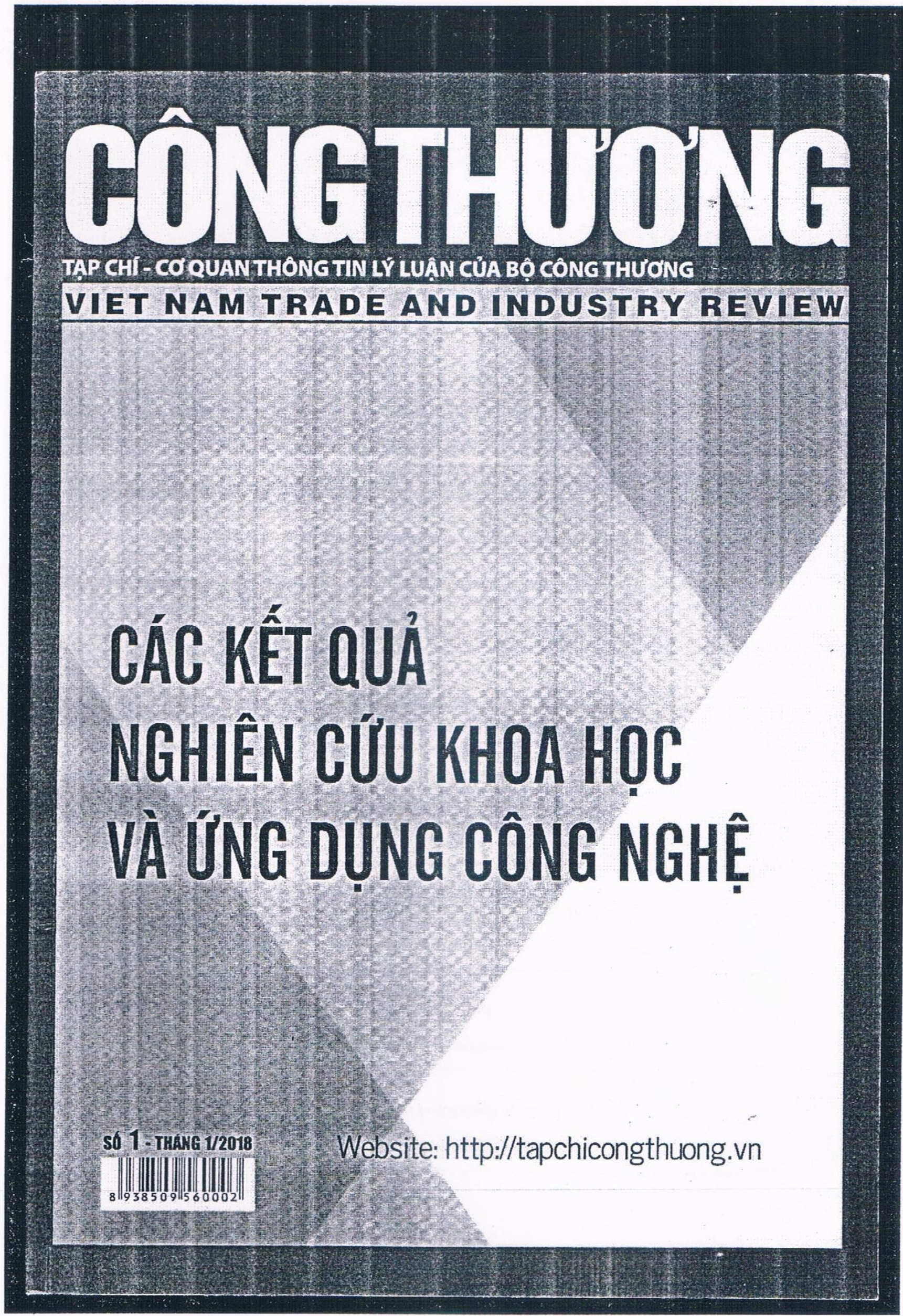




\section{KINH DOANH}

\section{LÊ ANH TUÃN}

Một sõ vãn đề về phát triển sản phẩm mới

Issues on new product development.

NGUYẼ̂N NGỌC DUY PHƯƠNG - ĐOÀN LÊ THÙY DƯƠNG

Ứng dụng mô hình chãp nhận công nghệ (tam) đo lường hành vi mua điện thoại thông minh

Application of technology acceptance model (tam) in measuring the purchase of smart phones

\section{NGUYẼN VĂN THANH TRƯỜNG}

Hoàn thiện hệ thỗng dịch vụ logistics chuỗi cung ứng lạnh của thực phẩm tươi tại Việt Nam

Improving the system of cold chain logistics services of fresh food in Vietnam

MAI Võ NGỌC THANH - TRỊNH DIỆU HIỀ - NGUYĚ̃ MINH TRIẼT

Ý định khởi sự doanh nghiệp của sinh viên các trường đại học và cao đẳng tại tỉnh Đồng Tháp

Business start-up intention of students at universities and colleges in Dong Thap province.

\section{CÁNH CHÍ HOÀNG - ĐặNG LIÊN MINH}

Các yểu tỗ ảnh hưởng đến ý định cung cãp thông tin riêng tư của khách hàng

khi mua săm trên các trang thượng mại điện tử khu vực TP. Hồ Chí Minh

The factors influencing the intention on providing private information of customer

when shopping on e-commerce sites in areas of Ho Chi Minh city.

\section{LÊ THÁI SƠN - HÀ NAM KHÁNH GIAO}

Phát triển du lịch MICE tại Đà Lạt - Kiểm định từ hướng cung

Developing MICE tourism in Da Lat - Verifcationfrom the direction of supply.....

\section{TÀI CHÍNH - NGÂN HÀNG - BẢO HIỂM}

\section{NGUYẼ̃N THU THỦY - TRẦN MINH NGOQC}

Tác động từ quản trị vỗn lưu chuyển đễn lợi nhuận hoọt động kinh doanh của các doanh nghiệp trên thị trường chứng khoán Việt Nam

Impact of working capital management to the profitability of listed firms in Vietnam

\section{HÀ THİ TRÚC LAN}

Nghị quyết sõ 42/2017/QH14 quy định về thí điểm xừ lý nợ xãu của các tổ chức tín dụng:

Những nội dung cơ bản, ưu điểm và hạn chẽ

Resolution No. 42/2017 / QH14 regulating the pilot implementation of bad debts of credit institutions:

The basic contents, advantages and limitations

\section{LÊ LONG HÂU - TÔN VĂN HÙNG}

Hoàn thiện công tác quản lý thu thuẽ giá trị gia tăng đỗi với doanh nghiệp

của Chi cục Thuể huyện Cai Lậy, tỉnh Tiền Giang

Improving the management of collection of value-added tax for enterprises

of Taxation Department of Cai Lay district, Tien Giang province

\section{NGUYẼ̃N VĂN KHÁNH - NGUYẼN HÔNNG HÀ}

Thực trạng và giải pháp nâng cao chất lượng dịch vụ tín dụng nông nghiệp nông thôn:

Trường hợp tại Agribank - Chi nhánh Trà Vinh

Situation and solutions to improve the quality of agricultural credit services in rural areas:

Case study at Agribank - Tra Vinh Branch 


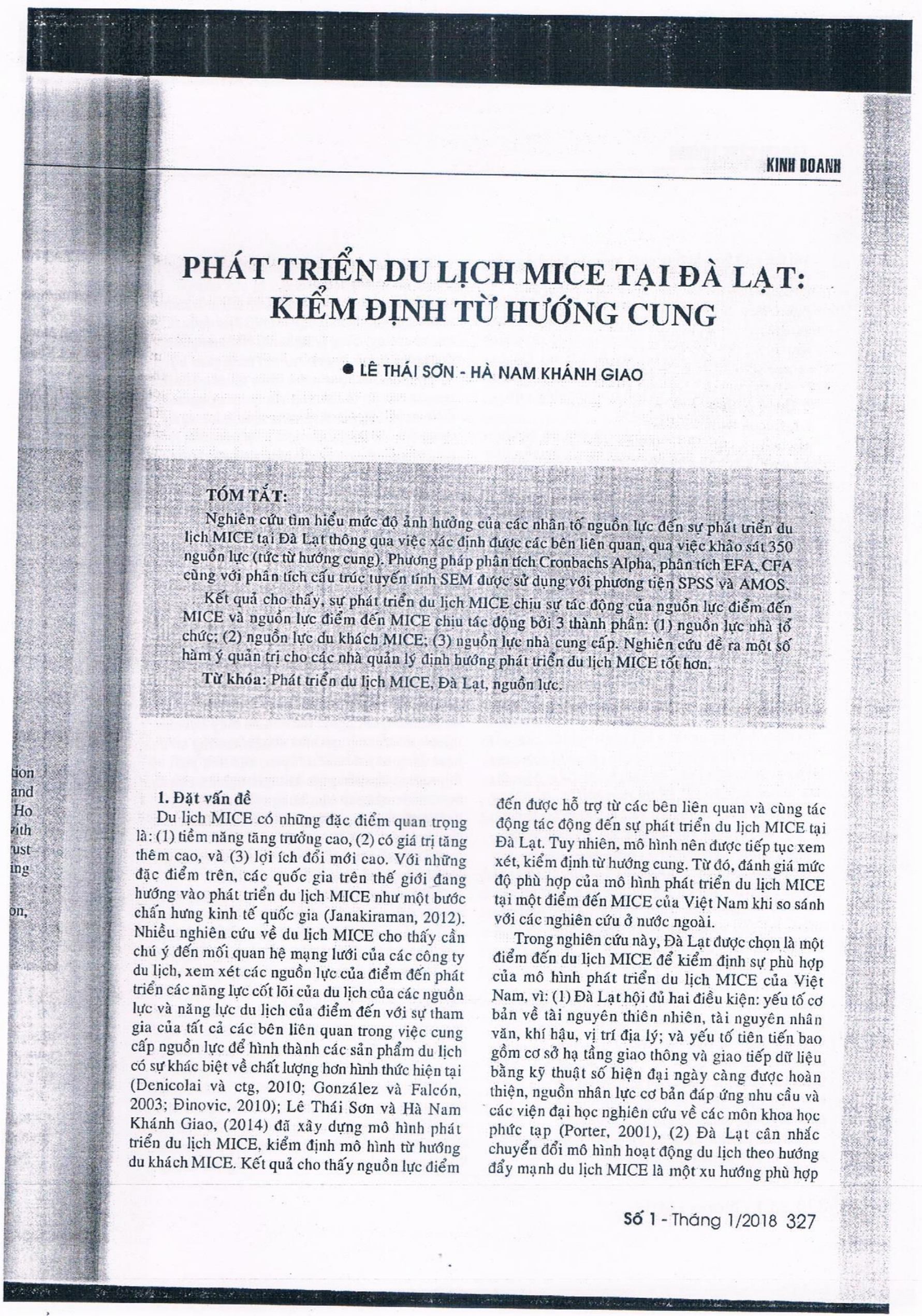


với thế giới theo hướng phát triển du lịch bền vững (Đinovíc, 2010), (3) Đà Lạt ngày càng được chọn tổ chức nhiều hội nghị, hội thảo hơn ở các cấp Chính phủ, các hiệp hội, các ngành, (4) Một khảo sát nhanh với 400 phiếu cho thấy tỷ lệ du khách đến tham dự các hoạt động MICE tại Đà Lạ chiếm $56,6 \%$ so với $43,4 \%$ du khách nghỉ dưởng.

2. Cơ sở lý thuyết và mô hình nghiên cứu

\subsection{Các lý thuyết nền tảng}

Michell và ctg (1997) nghiên cứu về các bên liên quan (stakeholders) cho rằng: "Các bên liên quan rõ ràng sẽ liên quan mật thiết với việc tích lũy số lượng các đặc tính của các bên liên quan là tính quyền lực (power); tính hợp pháp (ligitimacy) và tính khẩn cấp (urgency) mà nhà quản trị phải nhận thức". Bên liên quan chỉ sở hữu một đặc tính được gọi là bên liên quan tiềm ẩn; Có được hai đặc tính được gọi là bên liên quan mong đợi và với ba đắc tính thì được gọi là bên liên quan rõ ràng. Các bên liên quan thường được xem xét gồm: (1) Tổ chức quản trị điểm đến (Destination Management Organization- DMO), Văn phòng khách hàng hội nghi (Customer visite Bureau- CIB) thường được xem là các tổ chức chuyên nghiệp, nhà quản lý; (2) Nhà điều hành, nhà tổ chức, tài trợ được xem xét riêng biệt trong từng bối cảnh nghiên cứu; (3) Trung gian tiếp thị thường là cầu nối giữa nhà cung cấp với điểm đến hoắc du khách với điểm đến; (4) Du khách MICE; (5) Điểm đến MICE; (6) Cộng đồng cư dân tại điểm đến và (7) Chính quyền.

Lý thuyết dựa vào nguồn lực (Acedo và ctg, 2006) gồm: Quan điểm dựa vào nguồn lực (resource-based view) - mỗi tổ chức độc lập đều có những cấu trúc nguồn lực cụ thể là những tài sản vất chất và khả năng sở hữu và/hoặc kiểm soát của mình, có tính riêng có, phát sinh từ lịch sử hình thành của nó; quan điểm dựa vào kiến thức (knowledge-based view) - sự thay đổi của môi trường kinh doanh sẽ ảnh hưởng đến cả hai phía cung - cầu (Cooper, 2006), nên các điểm đến phải liên tục thích ứng bằng cách tao ra, sử dụng kiến thức cần thiết để đáp ứng với 'sự thay đổi; và quan điểm về các mối quan hệ (relational view) - khi tham gia vào một mạng lưới mới, năng lực của từng bên liên quan sẽ được phát triển mạnh mẽ hơn, điều này cũng đúng đối với một điểm đến.

2.2. Mối quan hệ giữa sự phát triển du lịch MICE và các nguồn lực nhân tố
2.2.1. Ảnh hưởng tù̀ nguồn lực nhà cung cấp đến

kiện đã guồn lực điểm đến MICE

Tất cả các sự kiện MICE đòi hỏi cung cấp nhiều hoạt động như vận tải nội địa, quốc tế thông qua các hãng, công ty lữ hành; Nới ăn nghỉ của các đoàn đại biểu, khách mời; Trung tâm hội nghi: Triển lãm; Dịch vụ nghe nhìn tại các khách sạn, resort cao cấp là thành phẩn quan trọng trong goi dịch vụ MICE. Ngoài những nguồn lực vật lý, nhà cung cấp còn có thể cung cấp thêm nguồn lực kiến thức và kết nối mạng. Nguồn cung cấp càng mạnh, điểm đến MICE càng có nhiều năng lực để tạo nèn sự phát triển.

$\mathrm{H} 1$ : Nguồn lực nhà cung cấp có tác động thuận chiều đến nguồn lực điểm đến MICE

2.2.2. Ảnh hưởng của nguồn lục nhà tổ chức đến nguồn lực điểm đến MICE

Các nhà tổ chức sử dụng uy tín, thương hiệu điểm đến, khả năng của mình (nguồn lực hứu hình và vô hình) để đăng cai, tổ chức sự kiện, thu hút thêm nguồn lực để phát triển điểin đến (Tingting và ctg, 2007). Các chính phủ thường là những nhà tổ chức, nhà tài trợ quan trọng để tổ chức hoạt động MICE nhà̀m thu hút các chuyên gia, khách du lịch trong và ngoài nước. Các hiệp hội chuyên gành và tổ chức phi lợi nhuận thường sử dụng hoạt động này để huấn luyện, xúc tiến phát triển thị trường, chuyển giao kết quả nghiên cứu khơ học... Các công ty lớn, công ty đa quốc gia cũng thường tổ chức hoạt động MICE nhăm đến nhu cảu của du khách MICE.

H2: Nguồn lực nhà tổ chức có tác động thuận chiều đến nguồn lực điểm đến MICE.

2.2.3. Ảnh hưởng của nguồn lực tổ chúc chuyên nghiệp đến nguồn lực điểm đến MICE

Tai các nước phát triển ở châu Âu, Mỹ, một số ước châu Á như Nhật Bản, Hàn quốc, Singapore.. các tổ chức chuyên nghiệp đã góp phần rất lởn trong việc tổ chức thành công một sự kiện MICE Các tổ chức chuyên nghiệp có thể hổ trợ cho điểm đến MICE nguồn lực dựa vào kiến thức và nguổn lực dưa vào mối quan hệ, họ dựa vào kỹ năng và kinh nghiệm của mình để gia tăng lượng thông tín cần thiết và quan trọng đến với du khách $\mathrm{MICE}$ Bên cạnh kinh nghiệm, mạng lưới mối quan hệ của các tổ chức chuyên nghiệp và các bên liên quan các tổ chức chuyên nghiẹ̀ vang cấp và du khách khác như nhà tổ chức, nhà cung cấp và du kỉn
H3:

động th

2.2 .4

đến ngı

Nhis

được đị trợ bơi nước พi:

MICE ।

những

khách $c$

đợi đó

MICE I

mà còr

văn hó.

thấy rà

khách 1

đổi ng.

(Dwye

$\mathrm{H} 4$ :

thuận c

2.2 .

MICE

Viê

nói riế

và các

(1999)

phát tr

ngành

phát tr

đầu tư

phát tr

vực là

MICE

MICE

H5

thuận 


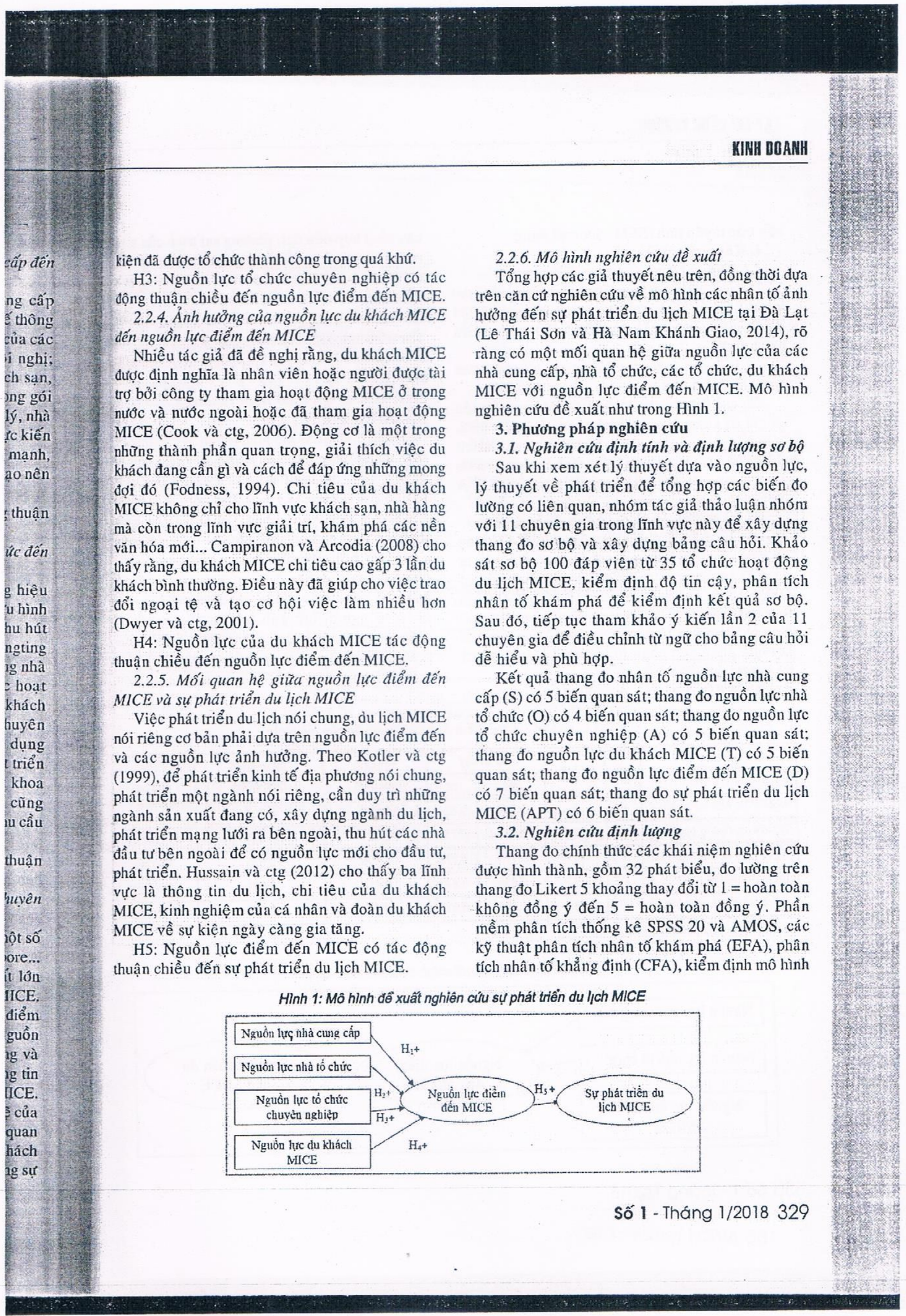




\section{IAPP CHI CÔNG THƯƠNG}

cấu trúc tuyến tính (SEM) được sữ dụng.

4. Kết quả nghiên cứu

4.1. Thống kê mô tả mẫu nghiên cứu

Tổng số phiếu điều tra phát ra 400 phiếu, thu về 350. Có 65 phiếu trả lời bị loại, kết quả có 285 phiếu điều tra hợp lệ $(71,25 \%)$ cho nghiên cứu chính thức.

4.2. Kết quả kiểm tra độ tin cậy và phân tích nhân tố khám phá

Kết quả Cronbachs Alpha của các thang đo đều có giá trị Cronchbachs Alpha từ 0,717 đến 0,88 , đảm bảo độ tin cậy. Kiểm định $\mathrm{KMO}$ và Barlett cho hệ số KMO và giá trị kiểm định Barlett có mức ý nghĩa sig. $=0,000<0,05$ cho thấy phân tích EFA là thích hợp.

\subsection{Phân tích nhân tố khẳng định}

Tiến hành phân tích nhân tố mô hình đo lường tới hạn, cho thấy kết quả mô hình có 308 bậc tự do, Chi-square $=494,328$ với $p=, 000$; các chỉ số $\mathrm{GFI}=0,890 ; \mathrm{TLI}=0,932 ; \mathrm{CFI}=0,940 ; \mathrm{RMSEA}=$ 0,046 nhỏ hơn 0,06 . Các chỉ số trên khảng định mô hình phù hợp với dữ liệu thị trường. Tổng hợp các kết quả phân tích nhân tố khẳng định (CFA) kể trên được thể hiện ở Bảng 1 .

Các số liệu ở Bảng 1 cho thấy độ tin cậy, độ tin cậy tổng hợp đều đạt; phương sai trích của mộtsó nhóm nhân tố nguồn lực nhà tổ chức, du khách MICE và uguồn lực điểm đến MICE có thấp hợ mức điều kiện 0,5 , trong khi các yếu tố tải nhân tó đều cao. Đây cũng là một hạn chế vì, mô hình hần đầu tiên được kiểm định về mặt lý thuyết. Mố hinh lý thuyết chính thức sau kiểm định được điều chỉnh như Hình 2.

4.4. Kiểm dịnh mô hình lý thuyết chính thìc (Xem Hinh 3)

Kiển định SEM mô hình (Hình 3) cho thấy. mô hình có 337 bậc tự do, chi-square $=563,468$ ( $p=$ 0,000), Chi-square/df $=1,672$ nhỏ hơn 2; Các chi số: $\mathrm{GFI}=0,881 ; \mathrm{TLI}=0,923 ; \mathrm{CFI}=0.931$ रें RMSEA $=0,049$ nhó hơn 0,06 . Điều này, khảng định mô hình phù hợp với dữ liệu thị trường.

Hệ số hồi quy chuẩn hóa của các tham số chính được trình bày ở Bảng 3 cho thấy các mói quan hệ này thuận chiều và dương từ các nhóm nhân tố nguồn lực ảnh hưởng đến nguồn lực điểm đến và nguồn lực điểm đến có ảnh hưởng thuận chiều đến sự phát triển và đều có ý nghĩa thống kê $(\mathrm{p}<0,05)$.

Bảng 1. Tóm tắt kêt quả kiểm định các thang đo của mô hlnh

\begin{tabular}{|c|c|c|c|c|c|c|c|}
\hline \multirow{2}{*}{ Thang đo } & \multirow{2}{*}{ Mā } & \multirow{2}{*}{ Sõ biễn } & \multicolumn{2}{|c|}{ Độ tin ca्ây } & \multirow{2}{*}{$\begin{array}{l}\text { Phuong } \\
\text { sai trich }\end{array}$} & \multirow{2}{*}{$\begin{array}{l}\text { Tải nhân tố } \\
\text { bình quân }\end{array}$} & \multirow{2}{*}{$\begin{array}{c}\text { Sự } \\
\text { phù hợp }\end{array}$} \\
\hline & & & $\alpha\rceil$ & $p c$ & & & \\
\hline Nguôn lực nhà cung cấp & S & 5 & 0,838 & 0,834 & 0,507 & 0,703 & Phù hợp \\
\hline Nguổn lực nhà tổ chức & 0 & 4 & 0,717 & 0,719 & 0,391 & 0,624 & Phù hợp \\
\hline Nguôn lực du khách MICE & $\mathrm{T}$ & 5 & 0,771 & 0,776 & 0,406 & 0,633 & Phù họp \\
\hline Điểm đến MICE & $D$ & 7 & 0,828 & 0,832 & 0,418 & 0,641 & Phù họp \\
\hline Sự phát triên du lı̣ch MICE & PT & 6 & 0,880 & 0,875 & 0,54 & 0,732 & Phù họp \\
\hline
\end{tabular}

Hinh 3

(1) 4 (2) -1 (a) -4 ()(2). (2)(ब) $=$ (2)(2) $=$ (2). (2): (iv) $\rightarrow$ (2)(3)-

\section{\begin{tabular}{|l}
\hline \\
\hline Nguổn \\
\hline Nguốn \\
\hline Nguởn \\
\hline Diểm ì \\
\hline
\end{tabular}} Nguồn: 5. 1 Kế ra là c (S); n kháct

Hinh 2: Mô hinh lý thuyết chính thức sau kiểm định

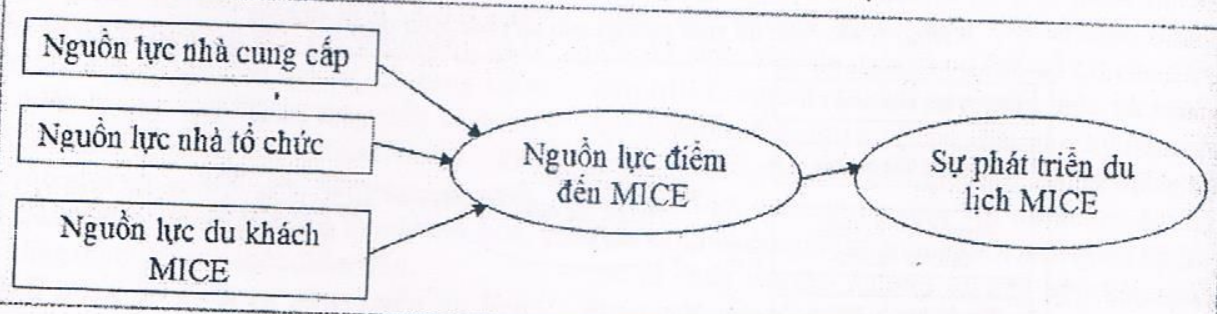

330 Số 1 - Tháng $1 / 2018$ 


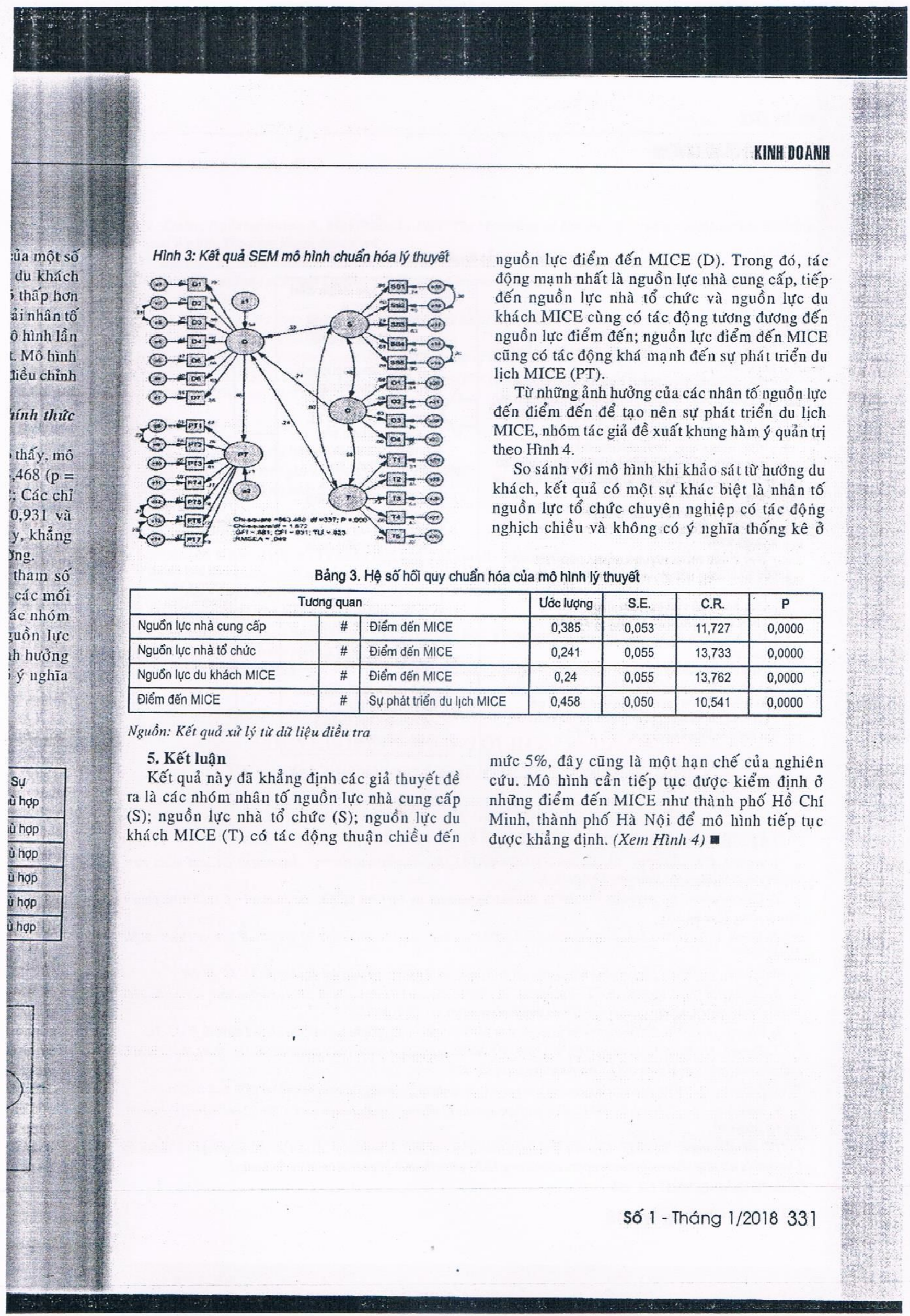




\section{TAP CHI CONNG THUU'NG}

Hinh 4: Hàm ý quản trı về sự phát triển du lıch MICE

* Tăng cường ngiứn lực cung cấ:

- Đâu tư hạ tâng du lịch phù hợp với xu hướng phát triển;

- Đầu tư phả triến trang thiết bị, công nghệ hiên đạ để tao thuận lợi cho cung cấp dịch vự

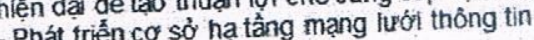
niên đại, kết nới mạng, internet:

- Phát triển mạng lưới dịch vụ bố sung

-

- Xây dựng quy nuhiêm từ các bên liên quan ta điểm đến.

* Tăng cường nquốn lực nhà tó́ chức

Tân trợ tổ chức cho nhiều loại sự kiện:

- Chú ý đến mối quan hè và sự phối hợp vờ - Chư y đến miêp hợi tố chức sự kiên tại điểm

đấn tốn:

Chú ý vai trò của cư dân điễm đến.

- Chú y va trocula cur dare du kách MICE

- Tăng cường nguơn lực du kiêm nắng trong và

ngoài nước:

- Tố chức chuỡi sự kiện có liên quan đến gia - Tưu văn hóa, găp gơ̆ cư dân để tạo điếu kiện trao đổi, chuyến giao kết quả nghiên cứu: trao đổ, chuyen glao kếm dịch vu cao cấp để - Đa dang hóa san pham dich. MiCE
Nguổn lực điểm đển MICE

- Có đủ nợ ăn nghỉ, vui chơi giài trí chất lexơng cao;

- Cung cấp phòng hộ nghi có tiêu chuấn cao

- Có trung tâm triển Iâm, vui chơi giảit tri; - Đa dạng hóa sàn phấm dịch vụ du lịch để thu hút đu khách. - Tiếp tục đào tạo, huấn luyện, bồ sung kinh nghiêm đế nhân viên phục vụ có trinh độ chuyên món ngày càng cao.

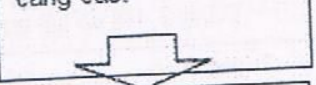

DU KHACH MICE - Đươc đáp ưng, phục vu nhu cầu của tơ nhất: - Có thêm kinh nghiệm, cơ hôi phát triến:

- Có thểm nhiêu mối quan hệ mới.

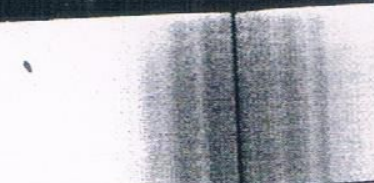

TÀI LIẾU THAM KHẢO:

1. Acedo, F.J., Barroso, C., Galan, J.L.

Strategic Management Journal, 27:621-636.

2. Campiranon, K., Arcodia, C., 2008. Market Segmentation in Time of Crisis. Journal of Travel và Ôourism Marketing, 23: 15I-161.

3. Cook, R.A., Yale, L.I. and Marqua, J.J., 2006. Tourism: The business of travel. Pearson Prentice Hall, NewYork.

4. Cooper, C., 2006. Knowledge management and tourism. Annals of Tourism Research, 33(1):47-64t worked core

5. Denicolai, S., Cioccarelli, G., Zucchella, A., 2010. Resource-based

competencies for tourism excellence. Tourism Man M MICE tourism in Montenegro. Selective Tourism, 5:17-31.

6. Binovic, L., 2010. Developmental prospects of Mutralia's MICE

7. Dwyer, L., Mistilis, N., Forsyth, P., Rao, P., 2001. In.

industry. International Journal of Tourism Research, 3: 123.
8. Fodness, D., 1994. Measuring tourist motivation. Annats of Tourism Research, 21(3): 555-581.

9. González, M., Falcón, G., 2003. Competitive potential of tourism in che 30(3): 720-740.

10. Janakiraman, S., 2012. Growth and importance of the MICE industry. Asia-Pacific business và technolog) biztechreport.com/story/1830-growth-and-importance-mice-industry]. 


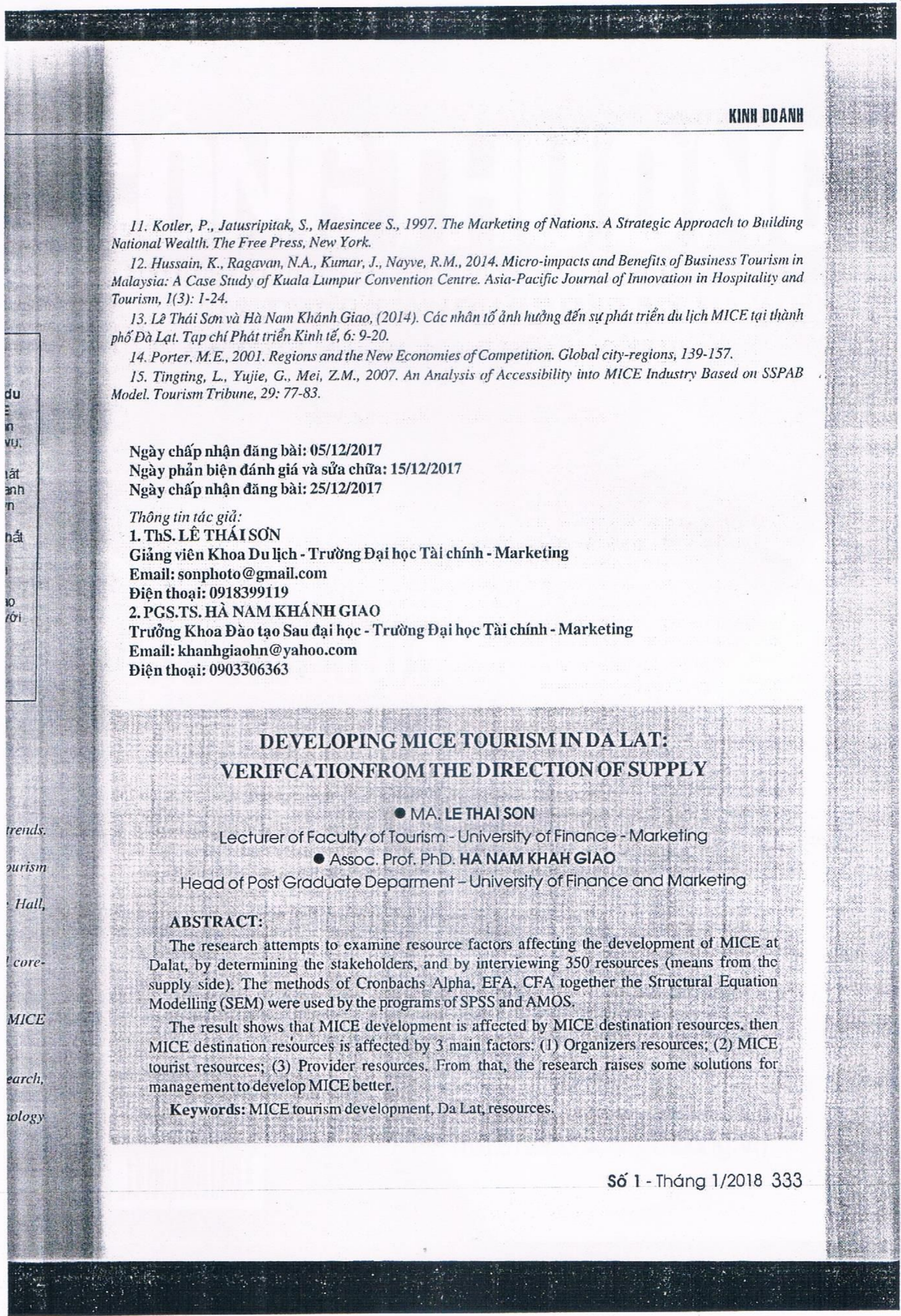

